HortSCIENCE 25(10):1304. 1990.

\title{
Variation in Wound Compartmentalization in Flowering Cherry Progenies
}

\author{
Frank S. Santamour, Jr.,' and Donald R. Egolf ${ }^{2}$ \\ U.S. National Arboretum, Agricultural Research Service, U.S. \\ Department of Agriculture, 3501 New York Avenue, N. E., Washington, \\ DC 20002.
}

Additional index words. Prunus, decay resistance, selection

The Asiatic flowering cherries \{Prunus. subgenus Cerasus, section Pseudocerasus) are usually considered to be short-lived trees. However, in 1975, it was estimated that $\approx 28 \%$ of the Japanese cherry trees planted around the Tidal Basin in Washington, D. C., in 1912 were still alive - after 63 years (Jefferson and Fusonie, 1977). Many of the surviving cherry trees in the Tidal Basin area and elsewhere around Washington, D. C., are, however, horticultural eyesores when not in flower. Although the cherries suffer from an abundance of insect and disease pests, it is obvious that one significant factor contributing to the less-than-optimum appearance of many trees is the amount of decay that has resulted from accidental or intentional wounding of the trees.

Recent research (Santamour, 1979) has shown that the ability of a tree to compartmentalize wood discoloration and decay that results from wounding is under moderate to strong genetic control. Strong- and weakcompartmentalizing trees exist in all tree species studied and this characteristic is not related to the growth rate of the tree. Tests for compartmentalization response can be made on very young trees (Santamour, 1984b). Furthermore, there appears to be a significant positive relationship between strong compartmentalization and graftability, since all of the tested commercial cultivars of landscape trees that had been propagated by budding or grafting were strong compartmentalizes (Santamour, 1984a, 1986).

The present study was undertaken to determine whether selection for strong compartmentalization potential might be feasible in flowering cherries. The cherry trees were open-pollinated progenies from the cultivars Kursar [P. nipponica var. kurilensis (Miyabe) Wils. $\times P_{-}$campanulata Maxim.], Okame $(P$. incisa Thunb. $\times P$. campanulata), and Umineko ( $P$. serrulata Lindl. $\times$

Received for publication 3 Feb. 1989. The cost of publishing this paper was defrayed in part by the payment of page charges. Under postal regulations, this paper therefore must be hereby marked advertisement solely to indicate this fact.

'Research Geneticist.

${ }^{2}$ Research Horticulturist.
P. incisa). The male parent of 'Kursar' was originally thought to be $P$. sargentii Rehd., but later was assumed to be $P$. campanulata (Ingram, 1970). In June 1986, 7-year-old trees were wounded by making two chisel cuts (1.6 cm wide and 0.2 to $0.5 \mathrm{~cm}$ deep) on opposite sides of the trunks at $1.5 \mathrm{~m}$ above ground level. Following an evaluation of tree form and flowering in Spring 1988, the majority of the trees were cut down and the extent of wood discoloration caused by wounding was observed by means of a crosssectional saw cut made through the wound zone.

Trees were rated as weak compartmentalizers if the discoloration from one or both chisel wounds extended, in a wedge-shaped pattern, to the pith. Strong-compartmentalizing trees essentially built a "wall" just interior to the deepest penetration of the chisel that prevented the further penetration of bacteria and fungi (Santamour, 1987). Crosssections of strong- and weak-compartmentalizing trees are shown in Fig. 1. Six trees were considered superior to the others in form and flowering, and these were not cut down. Wound compartmentalization in these trees was determined by increment borings through the wounds.

Of 45 trees tested, 25 (55.6\%) were found to be strong compartmentalizes. The proportion of "strong" to "weak" trees varied among the progenies: 'Kursar' (7:5), 'Okame' (14:5), 'Umineko' (4:10). Of the six trees originally selected as superior, five were strong and one was weak.

The mode of inheritance of wound compartmentalization potential has not been determined in any tree species. The data presented here do, however, indicate that weak-compartmentalizing, decay-susceptible trees may constitute a significant proportion of some seedling populations. We advocate the inclusion of this simple wound ing test as a selection criterion in developing superior flowering and fruiting cherry cultivars.

\section{Literature Cited}

Ingram, C. 1970. A garden of memories. H.F. Witherby, London

Jefferson, R.M. and A. E. Fusonie. 1977. The Japanese flowering cherry trees of Washington, D.C. USDA National Arboretum Contrib. 4.

Santamour, F.S., Jr. 1979. Inheritance of wound compartmentalization in soft maples. J. Arboric. 5:220-225.

Santamour, F. S., Jr. 1984a. Wound compartmentalization in cultivars of Acer Gleditsia, and other genera. J. Env. Hort. 2:123-125.

Santamour, F. S., Jr. 1984b. Early selection for wound compartmentalization potential in woody plants. J. Env. Hort. 2:126-128.

Santamour, F. S., Jr. 1986. Wound compartmentalization in tree cu!tivars: Addendum. J. Arboric. 12:227-232

Santamour, F, S., Jr. 1987. Building walls and breaching walls; Truth and consequences in wound compartmentalization. J. Arboric. 13:262-266.

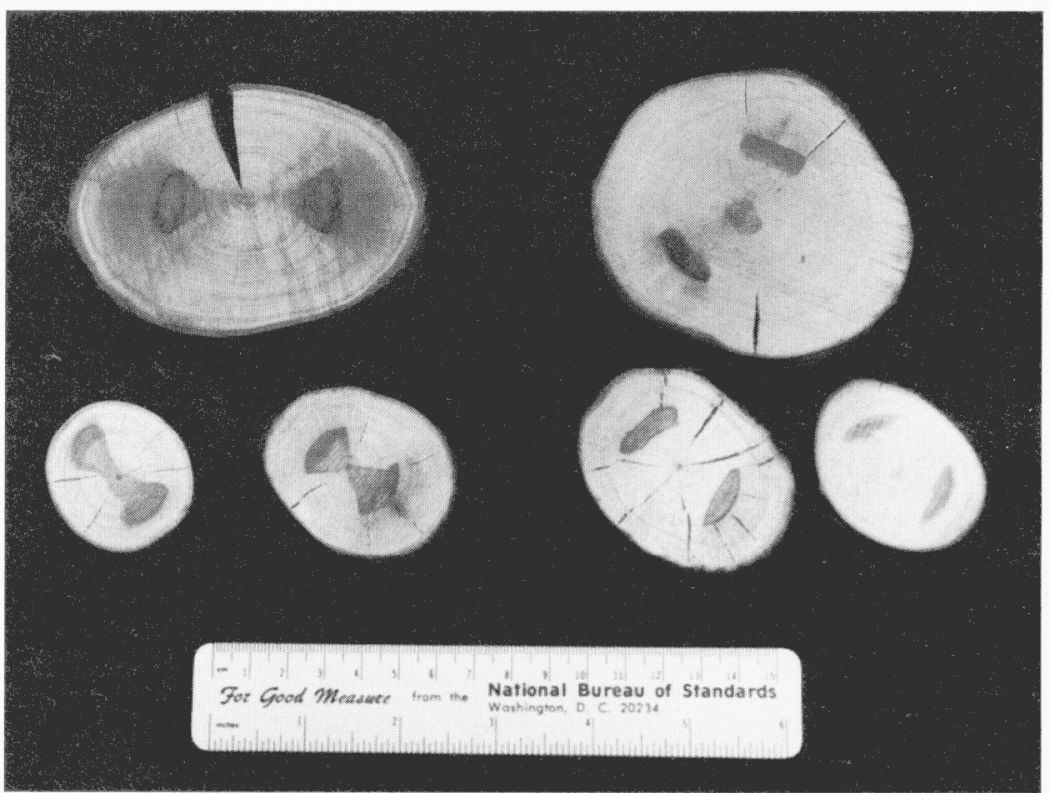

Fig. 1. Cross-sections of chisel-wounded cherry trees: (left) weak-compartmentalizing trees showing trunk discoloration to center of trunk,(right) strong-compartmentalizing trees with discoloration limited to wounded area. 